\title{
Environmental Settings in The Indonesian Constitution Perspective
}

Taufiqurrohman Syahuri, Lecturer at the Faculty of Law of "Veteran" National Development University of Jakarta Indonesia, tsyahuri@gmail.com, ORCID: 0000-0008-0010-2056-0765

Wahyu Nugroho, Lecturer at the Faculty of Law, Sahid University Jakarta Indonesia, wahyulaw86@yahoo.com, ORCID.0000-0003-1945-0434

Ibnu Sina Chandranegara, Lecturer at the Faculty of Law, Muhammadiyah University Jakarta Indonesia, ibnusinach@umj.ac.id, ORCID:0000-0002-8828-1614

Wendra Yunaldi, Muhammadiyah University West Sumatra West Sumatra Indonesia wendrayunaldi78@gmail.com, ORCID:0000-0010-2987-0877

Abstract. The renewal of the Indonesian constitution in the fourth amendment to the 1945 Constitution provides a policy format or political law for the national economy taking into account the principle of environmental and sustainable insight. The problems in this paper are first, how are environmental arrangements in the Indonesian constitution? and second, what is the contribution of environmental regulation in the Indonesian constitution to natural resource management policies? The results of this study are first, the environmental regulation in the Indonesian constitution is inseparable from the development of the international environment and the principles of sustainable development formulated in WCED United Nations. Economic constitution through Article 33 paragraph (3) of the 1945 Constitution still tends to be anthropocentric approach, so it must be balanced and correlated to paragraph (4) in this provision which is characterized by a green constitution through the principles of togetherness, fair efficiency, sustainability, environmental insight, independence, and by maintaining the balance, progress and unity of the national economy; secondly, the contribution of environmental regulation in the Indonesian constitution to natural resource management policies. In an effort to control and exploit it is not only the interests of economic commodities to achieve state revenue alone, but also consider environmental aspects. Environmental constitutionality contributes significantly in providing a balance between national development and environmental balance.

Keywords: constitution, country, environment, sustainable development, natural resources

Received: 04.12.2020 Accepted: 16.01.2021 $\quad$ Published: 03.02.2021

\section{INTRODUCTION}

In general the constitution and the state are two institutions inseparable to one another, even after the Middle Ages it can be said, without a constitution one state would not be possible to be formed. Every country must have a constitution, let alone an independent state. For the state and nation, the constitution is something that is very important both long-term independence and those states that just gained independence. Understanding the constitution according to "Corpus Juris Scundum" volume 16, is:

"A constitution is the original law bay which a system of government is created and set up, and to which the branches of government must look for all their power and authority" (Corpus Juris Scundum, t.th).

The term constitution according to Wirjono Prodjodikoro comes from the verb "constituer" in French which means "to form"; so constitution means formation (Wirjono Prodjodikoro, 1977). In this case, what is formed is a state, then the constitution contains the beginning of all kinds of basic regulations concerning the first joints to enforce a large building called the state (C.A.J.M. Kortmann, 1960). The term constitution is not actually used to refer to only one understanding. In practice, the term constitution is often used in several senses. In Indonesia, besides the term known as the constitution, the term constitution is also known. Likewise in the Netherlands, besides the term known as "groundwet" (basic law) the term is also known as "constitutie".

The constitution can be interpreted as a written document which outlines the legislative, executive and judicial powers and other important state institutions. Constitution with other terms such as constitution or verfasung is distinguished from the basic law or groundgesetz. Herman Heller stated that the constitution has a broader meaning than the basic constitution (Moh. Kusnardi and Harmaly Ibrahim, 1983). Solly Lubis 
argued, the constitution has two meanings: written constitution (basic law) and unwritten constitution (convention) (M. Solly Lubis, 1978), and the United Kingdom as an example of a country that does not have a written constitution (Muhammad Tahir Azhari, 1992).

Besides being a juridical constitution it also has sociological and political significance. This view is in line with the opinion of Herman Heller, a German scholar, who divided the notion of the constitution into three terms: (a) The constitution reflects political life in society as a reality (Die politische verfassung als gesellschaftliche Wirklichkeit) and it is not yet a constitution in the legal sense ( ein Rechtsverfassung) or in other words the constitution is still a sociological or political understanding and is not yet a legal definition; (b) after people search for the legal elements of the constitution that lives in the community to be made as a unity of the rule of law, then the constitution is called Rechtverfassung (Die verselbastandigte Rechtverfassung); (c) then people start writing it in a text as the highest law in force in a country. (Moh. Kusnardi and Harmaly Ibrahim, 1983).

While K.C. Wheare F.B.A in the book Modern Constitution, explains the term constitution, in big lines it can be differentiated into two definitions, namely:

First the term constitution is used to refer to all the rules regarding the constitutional system. Second, the term constitution refers to a document or a number of documents containing certain rules and provisions which are of a basic or basic nature regarding the statehood of a country. (K.C.W. Wheare F.B.A, 1975).

In addition, the constitution also contains the definition of: "A constitution as a form of social contract joining the citizens of the state and defining the state itself" (Dennis C.Mueller, 1996). Jimly Asshiddiqie, professor of constitutional law at the University of Indonesia in his book by referring to Jackson, Vicki C, and Mark Tushnet, detailed the constitutional functions such as:

a) The function of determining and limiting the power of state institutions.

b) The function of regulating power relations between state institutions.

c) The function of regulating the relationship of power between state institutions and citizens.

d) The function of the giver or source of legitimacy to state power or the activities of the administration of state power.

e) The function of channeling or transferring authority from the original source of power (which in the democratic system is the people) to state institutions.

f) Symbolic function as a unifier (symbol of unity), as a reference to national identity and grandeur (identity of nation), as well as the center of ceremony.

g) The function of social engineering or social reform and social control (Jimly Asshiddiqie, 2002).

Based on the description above, it can be drawn an understanding that the definition of the constitution and the 1945 constitution refers to the understanding of the basic law of a country, which governs the organizational structure of government (KC Wheare, 1975), establishes state bodies and the way they work, establishes the relationship between government and citizens (Ivor Jenning, 1960), and oversees the implementation of government (Russell F. Moore, 1957). The difference only lies in the process of the constitution. In Indonesia itself the two terms have been used, namely when in 1945 and 1950, the basic law of the Indonesian state was named with the term "constitution" namely the 1945 Constitution and the 1950 Provisional Constitution. While in 1949 the Indonesian state used the term "constitution" to refer to the basic law of the United Republic of Indonesia Constitution.

In relation to the environment, the 1945 Constitution places the state in possession of the right to control and manage natural resources in the context of national economic development by always observing the principles of environmental insight. The state does not only pursue economic growth, but how to ensure environmental and sustainable insights remain a consideration, and guarantee the right to a good and healthy environment as part of human rights.

\section{Problems}

In this paper, the problems are first, how are environmental arrangements in the Indonesian constitution? second, what is the contribution of environmental arrangements in the Indonesian constitution to natural resource management policies?

\section{RESEARCH METHOD}

The research method used in this paper is normative legal research with secondary data collection, namely legislation and literature, while descriptive qualitative data analysis is based on picture or portrait relating to 
environmental arrangements in the Indonesian constitution, and includes its contribution to resource management policies.

\section{RESEARCH RESULTS AND DISCUSSION}

\section{Indonesian Constitution}

Constitution was born as a demand and hope of the people to achieve justice. With the establishment of the state and constitution, the community surrenders certain rights to the state administrators. However, every member of society in the state retains his rights as a person. The state and constitution were established to guarantee these human rights. These rights were the starting point for the formation of a state and constitution. Indonesia's experience since the planned establishment of an independent Indonesian state until now (2019) has had several constitutions such as the constitution with the term Basic Law version BPUPKI (Indonesian Independence Investigation Preparatory Body) a body formed by Japan before Indonesia's independence. The Constitution of the Republic of Indonesia established by PPKI (Committee for the Preparation of Indonesian Independence) on 18 August 1945 the day after Indonesia proclaimed its independence. The Constitution of the United States of Indonesia in 1949 as a result of negotiations with the Netherlands which recognized the sovereignty of an independent Indonesian state in the form of a Federal state. The Constitution of the Republic of Indonesia Provisional Constitution of 1950 which returned to the form of the Unitary State of Indonesia (NKRI). The 1945 Constitution of the Presidential Decree version July 5, 1959 and finally the 1945 Constitution of the Republic of Indonesia Constitution (1945 Constitution) as a result of the 1999-2002 amendment to the 1945 Constitution version of the Presidential Decree (Taufiqurrohman Syahuri, 2004). This constitutional amendment applies now as the Indonesian constitution. Amendments to the 1945 Constitution have resulted in the total number of 75 articles, however the number of article numbers remains the same, 37 , as the original text. This is because the way of writing the article number is done by adding letters (A, B, C and so on) after the number. As Article 28 which regulates human rights, Article $28 \mathrm{~A}$ is written up to Article $28 \mathrm{~J}$.

\section{Environmental arrangements in the Indonesian constitution}

Among the 37 Articles in the 1945 Constitution, there is Article 33 which regulates the chapter on the national economy and social welfare. Article 33 originally contained three verses, after the amendment was added by two verses to become five verses. Paragraph 4 regulates the national economy based on economic democracy based on the principles of togetherness, fair efficiency, sustainable, environmentally friendly, independent, and by maintaining a balance of progress and national economic unity, while paragraph 5 only regulates the implementation of further provisions regarding the implementation of this article. in law. The meaning of "regulated by law" then gave birth to Law Number 32 of 2009 concerning Environmental Protection and Management which has been amended twice. The renewal of the Indonesian constitution which places the principle of environmental and sustainable insight into making the Indonesian constitution pro-environment, that in the end it is termed as the green constitution'.

According to Jimly Asshiddiqie, 'green constitution' applies environmental sovereignty or 'ecocracy', where the environment is no longer an arbitrary object in the human brain, but the environment is a subject that has its own rights to be conserved and protected from damage (Jimly Asshiddiqie, 2009). Green constitution was first discovered in the fourth amendment of the 1945 Constitution of the Republic of Indonesia. With the adoption of green constitution in the Indonesian constitutional system, it can become a legal basis for environmental management that is environmentally friendly and can help maintain environmental sustainability in order to remain clean and healthy so that it can be inhabited by the community and can be passed on to future generations of the nation. The right to a good and healthy environment is a part of human rights that cannot be violated by anyone and this has been guaranteed by the 1945 Constitution of the Republic of Indonesia..

In Article 28J paragraph (1) of the 1945 Constitution of the Republic of Indonesia, it is said that everyone must respect the human rights of others in the orderly life of society, nation and state. The right to a healthy environment is also guaranteed in Article 28H Paragraph (1) of the 1945 Constitution which states that "every person has the right to live in physical and spiritual prosperity, to live and to have a good and healthy environment and to have health services". From the sound of the above article, it is known that the 1945 Constitution of the Republic of Indonesia provides guarantees for every citizen to get a good and 
healthy environment and place to live. The existence of articles containing environmental norms proves that Indonesia adheres to green constitution in its constitutional system.

The concept of environmental democracy places Indonesia as a country that is very concerned about environmental issues in every national economic policy and development (Wahyu Nugroho, 2014). The constitutionality of state control over natural resources that takes into account the principle of environmental and sustainable insight is explicitly stated in Article 33 paragraph (4) of the 1945 Constitution: "National economy is organized based on economic democracy with the principles of togetherness, fair efficiency, sustainable, environmentally sound, independence, and by maintaining the balance, progress and unity of the national economy ". The principles in economic development that are based on Article 33 paragraph (3) of the 1945 Constitution state: "The earth and water and natural resources contained therein are controlled by the state and used for the greatest prosperity of the people" as a paradigm in mastery, utilization, and management of natural resources that are biased towards the anthropocentric approach, able to be balanced with the principles of economic balance, social justice, and the environment.

As a new development in providing interpretation of the meaning of "controlled by the state", based on the decision of the Constitutional Court against the review of Law No. 20 of 2002 concerning Electricity (Case Decision number 011-021-021 / PUU-1/2003) that the state has authority called regelendaad, bestuursdaad, beheersdaad, and toezichthoudensdaad, namely to regulate, administer, manage and supervise. The people collectively constructed by the 1945 Constitution mandated the state to carry out several functions including: policy (beleid) and management actions (bestuursdaad), regulation (regelendaad), management (beheersdaad), and supervision (toezichthoudensdaad) for the purpose of maximum prosperity of the people (Achmad Sodiki, 2013).

In the context of interpreting the right to control the country, if there are problems in carrying out one or more of the functions mentioned above, new problems will emerge, for example if the management function in issuing permits or revoking licenses is not done properly, there will be violations of territorial boundaries that arise permitted to be managed or not carried out revocation of permits that have been given, even if a violation occurs. Thus the monitoring function that does not run well, will have an impact on environmental damage that is very severe and the recovery process in a long time, of course, very detrimental to current and future generations. This makes the principle of sustainable development not working, there will be inequality across generations.

The Indonesian Constitution in its amendments regulates environmental issues to ensure that the state controls over natural resources takes into account the environment and applies the principle of sustainable development, and cannot be separated from the history of international environmental development relating to the principle of sustainable development.

With regard to sustainable development, the United Nations General Assembly has an Institution called the World Commission on Environment and Development (WCED) in 1983 or often referred to as the Brundtland Commission, and in 1987 issued a report entitled "Our Common Future" and popularized the term sustainable development which influences international policy making (World Commission on Environment and Development, 1987). WCED then defined sustainable development as:

"Development that meets the needs of the present without compromising the ability of future generations to meet their own needs. It contains within two key concepts:

1. The concept of 'need', in particular the essential needs of the world's poor, to overriding priority should be given; and

2. The idea of limitations imposed by the state of technology and social organization on the environment's ability to meet present and future".

Based on this, elements of sustainable development can be seen based on the definition of WCED, including the principle of integration, the principle of sustainable use, the principle of intra-generational equity, and the principle, and the principle of intergenerational equity.

Philippe Sands devided continous development into several principles, namely:

a Intergenerational equity, which can be seen from the need to protect natural resources for the benefit of future generations;

b. The sustainable use principle, which is reflected in the exploitation of natural resources in a sustainable, prudent, rational, wise, and appropriate manner;

c. Intragenerational justice, which is demonstrated through the equitable use of natural resources, in which the utilization of natural resources by one country must still pay attention to the needs of other countries; and 
d The principle of integration, which requires a guarantee that environmental considerations will be integrated into plans, policies, and programs related to the economy and development, and that meeting the needs of development must pay attention to the objectives of environmental protection (Philippe Sands, 1994).

The Indonesian Constitution which is based on the principle of sustainable development in international law through WCED United Nations, then gave birth to the concept of sustainable development in the Indonesian legal system formulated in law number 32 of 2009 concerning Environmental Protection and Management as a "conscious and planned effort that combines aspects of environmental, social and economic aspects into development strategies to ensure the integrity of the environment and the safety, capability, welfare and quality of life of present and future generations".

\section{Contribution of environmental arrangements in the Indonesian constitution to natural resource management policies}

The birth of ideas or thoughts of the green constitution, namely the constitution that cares about the environment has two objectives, namely: "the first is to encourage state authorities to make more futureoriented deliberations and decisions, the second is to create more public awareness and improve the process of public deliberation about issues affecting near and remote future generations" (Kristian Skagen Ekeli, 2007). Actually Article 33 paragraph (3) of the 1945 Constitution as a constitutional basis in natural anthropocentric resource management policies, so it must be balanced with the principles of environmental insight and sustainability as stated in Article 33 paragraph (4) of the 1945 Constitution. The two paragraphs cannot be interpreted, understood and interpreted separately, but understood and interpreted holistically and integrally.

The concept of state controls over Indonesia's natural resources is the will of the Indonesian people so that these natural resources provide the greatest prosperity to the people. The prosperity of the people will be obtained if the control of natural resources is used properly and correctly. As an effort to achieve people's prosperity over natural resources, these natural resources must be sought. Mastery and exploitation are of unity of actions / activities that are interconnected between the two (Ahmad Redi, 2014).

The meaning of being controlled by the state clearly limits the actions and legal relations that can be carried out by the state. State power in utilities has an impact on people's prosperity, thus a control by the state must be of good quality or connected and oriented towards prosperity. The control is carried out by the state, but if the control does not provide the prosperity of the people, then the mastery is not in accordance with the authority mandated in Article 33 of the 1945 Constitution.

The Indonesian Constitution in the fourth amendment to Article 33 of the 1945 Constitution, specifically paragraph (4) provides a constitutional contribution that in every state administration through its legal policies or politics for the management of natural resources, paying attention to efficiency, transparency, sustainability and environmental insight as its guidelines (Wahyu Nugroho, 2018). Exploitation of natural resources is not only in the interest of economic commodities to achieve state revenue alone, but social and environmental aspects are inseparable part of exploitation of natural resources. In the context of the environment, it is not only the principle of exploitation of natural resources, but environmental aspects are included in the business process that must be fulfilled by business actors, for example environmental administration instruments, namely environmental permits such as environmental impact analysis (Amdal), environmental permit, Environmental Management Efforts - Environmental Monitoring Efforts (UKL-UPL) (Helmi, 2012). In addition, an important instrument is the Strategic Environmental Assessment (KLHS), to ensure that the principles of sustainable development have become the basis and integrated in regional development and policies, plans and programs, in the regime of environmental protection and management arrangements.

Environmental constitutionality will be a real contribution in the framework of providing a balance between national development utilizing natural resources with a balance in environmental preservation, as well as a variety of investments both nationally and regionally that have a direct impact on the environment. This matter becomes urgent because it is related to the commitment of state administrators and business actors in implementing the principles of efficiency with justice, sustainability and environmental insight. Natural resource management policies that pay attention to environmental aspects in Indonesia are very concerned about local wisdom based on community culture, both in the order of traditional communities and indigenous peoples in the natural resource area. Based on the Indonesian constitution listed in Article 18B paragraph (2) of the 1945 Constitution states: "the state recognizes and respects the indigenous peoples units 
along with their traditional rights as long as they are still alive and in accordance with the development of society and the principles of the Unitary State of the Republic of Indonesia, which are regulated in the law".

The state will be judged as violating the constitution and the right to a good and healthy environment for the citizens, if it is inconsistent and being consequent in carrying out the constitution of the environment in every policy on the control and management of natural resources. The right to the environment becomes part of human rights, which is also reflected in the constitution, namely article 28H paragraph (1) of the 1945 Constitution, states: "every person has the right to live in physical and spiritual prosperity, to live, and obtain a good and healthy environment and entitled to receive health services." State control in natural resource management that does not reflect the principles of environmental insight, sustainability and social justice, only to pursue economic growth, infrastructure, investment, and local revenue, will result in environmental damage, and end in violation of rights possessed by the citizens to get a good and healthy environment as part of human rights.

The commitment of the state through the central government in implementing the environmental constitution, is then also followed by the regional government based on the principle of regional autonomy and Law Number 23 of 2014 concerning Regional Government. In the case of natural resource and environmental management which results in damage and no effort is made to repair it, which end up in causing floods, forest fires, landslides, or other natural disasters that violate the law and morality in their management. It is fitting that in terms of natural resource management and the environment is not merely pursuing success targets, but also at the same time paying attention to future generations.

Justice for future generations demands the just saving principles, namely the principle on which every policy and implementation of natural resources and the environment is always oriented to justice for the future generation, that is, bequeathing natural resources and a good environment for future generations not to inherit the state of the environment which was destroyed because of being exploited by the present generation. Instead, there must be a policy to refrain from overexploitation, especially of renewable natural resources, to guarantee the interests of future generations.

\section{Implication}

Based on the results of research and discussion in this paper, it can be concluded that first, environmental regulation in the Indonesian constitution is inseparable from the development of the international environment and the principles of sustainable development formulated in WCED United Nations. Economic constitution through Article 33 paragraph (3) of the 1945 Constitution still tends to be anthropocentric approach, so it must be balanced and correlated to paragraph (4) in this provision which is characterized by a green constitution through the principles of togetherness, fair efficiency, sustainability, environmental insight, independence, and by maintaining the balance, progress and national economic unity; secondly, the contribution of environmental regulation in the Indonesian constitution to natural resource management policies. In an effort to control and exploit it is not only the interests of economic commodities to achieve state revenue alone, but also consider environmental and sustainable insights, thus it becomes an integral part of the exploitation of natural resources. Environmental constitutionality contributes significantly in providing a balance between national development utilizing natural resources with a balance in environmental preservation, as well as a variety of investments both nationally and regionally that have a direct impact on the environment. The state will be judged to be in violation of the constitution and the right to a good and healthy environment of citizens, if it is inconsistent and not being concequent in carrying out the constitution of the environment in every policy on the control and management of natural resources.

\section{REFERENCES}

Asshiddiqie, Jimly. (2002). Indonesian Constitution and Constitutionalism in the Future, Jakarta: Center for Constitutional Law Studies, Faculty of Law, University of Indonesia, Jakarta.

Azhari, Muhammad Tahir. (1992). State of Law, Jakarta: Bulan Bintang.

Barendt, Eric. (1998). An Introduction to Constitutional Law, London: Oxford University Press.

Corpus Juris Scundum. (t.th). Constitutional Law, volume 16, Brooklyn, N.Y. The American Law Book.

Ekeli, Kristian Skagen. (2007). "Green Constitutionalism: The Constitutional Protection of The Future Generations", Ratio Juris, Vol. 20, No. 3 September.

Helmi. (2012). Environmental Licensing Law, Cet. 1, Jakarta: Sinar Grafika. 
Jackson, Vicki C, and Mark Tushnet. (1997). Comparative Constitutional Law, New York, Foundation Press.

Jenning, Ivor. (1960). The Laws and the Constitution, University of London. Kortmann, C.A.J.M. (1960). Constitutionalrecht, Kluwer, Deventer.

Kusnardi, Moh. and Harmaly Ibrahim. (1983). Indonesian Constitutional Law, Jakarta: HTN Study Center.

Lubis, M. Solly. (1978). Principles of Constitutional Law, Bandung: Alumni.

Moore, Russell F. (1957). Basic Comparative Government and Modern Constitution, Iowa.

Mueller, Dennis C. (1996). Constitutional Democracy, Oxford University Press.

Nugroho, Wahyu. (2014). "The Constitutionality of Customary Law Community Rights in Managing Customary Forests: Empirical Facts on Licensing Legalization", Journal of the Constitution, Volume 11, Number 1, March.

Nugroho, Wahyu. (2018). "Mining Management Policy and Customary Law Community with Ecological Justice", Constitutional Journal, Volume 15, Number 4, December.

Prodjodikoro, Wirjono. (1977). The Principles of State Administration in Indonesia, Jakarta: Dian Rakyat. Redi,

Redi, Ahmad. (2014). Natural Resources Law in the Forestry Sector, Cet. I, Jakarta: Sinar Grafika.

Rousseau, Jean-Jacques Rousseau. (1991). The Social Contrat and Discourses. Translation in English by G.D.H. Cole, J.M.Dent \& Sons Ltd, London, Reprinted.

Sands, Philippe. (1994). "International Law in the Field of Sustainable Development", British Yearbook of International Law, Volume 65, Issue 1.

Sodiki, Achmad. (2013). Agrarian Law Politics, Cet. 1, Jakarta: Constitution Press. Syahuri,

Taufiqurrohman. (2004). Constitutional Law, Jakarta: Ghalia Indonesia.

Wheare F.B.A, K.C.W. (1975). Modern Constitution, London: Oxford University 